JERZY BIELUK ${ }^{1}$

\title{
Dział spadku obejmującego gospodarstwo rolne w świetle przepisów ustawy o kształtowaniu ustroju rolnego
}

\section{Uwagi ogólne}

Ustawa z dnia 11 kwietnia 2003 roku o kształtowaniu ustroju rolnego ${ }^{2}$ po nowelizacji wprowadzonej ustawą z dnia 14 kwietnia 2016 r. o wstrzymaniu sprzedaży nieruchomości Zasobu Własności Rolnej Skarbu Państwa oraz o zmianie niektórych ustaw $^{3}$ przewiduje szereg ograniczeń w obrocie nieruchomościami rolnymi, obowiązujących od 30 kwietnia 2016 r. $^{4}$

Od 30 kwietnia 2016 r. rygorami u.k.u.r. objęto również sytuacje, w których do nabycia nieruchomości rolnych dochodzi w wyniku dziedziczenia ${ }^{5}$. Razem z nowelizacją u.k.u.r. zmieniono również Kodeks cywilny ${ }^{6}$, wprowadzając do art. 210 i $213 \mathrm{kc}$. odpowiednie zapisy nakazujące odpowiednie stosowanie tejże ustawy do znoszenia współwłasności nieruchomości rolnych. Zgodnie z art. 1035 kc., jeżeli spadek przypada kilku spadkobiercom, do wspólności majątku spadkowego oraz do działu spadku stosuje się odpowiednio przepisy o współwłasności w częściach

\footnotetext{
Uniwersytet w Białymstoku.

Tekst jedn. Dz.U. z 2016 r. poz. 2051 z późn. zm., dalej: u.k.u.r.

Dz.U. poz. 585.

Szerzej m.in. zob. J. Bieluk, Ustawa o kształtowaniu ustroju rolnego. Komentarz, Warszawa 2016; Z. Truszkiewicz, Nieruchomość rolna i gospodarstwo rolne w rozumieniu U.K.U.R., „Krakowski Przegląd Notarialny” 2016, nr 2, s. 139-168, H. Ciepła, Aspekty prawne obrotu gruntami rolnymi od 30.04.2016 r. o kształtowaniu ustroju rolnego oraz w ustawie z dnia 14.04.2016 r. o wstrzymaniu sprzedaży nieruchomości Zasobu Własności Rolnej Skarbu Państwa, „Rejent” 2016, nr 9, s. 33-82; K. Maj, Zmiany w ustawie o kształtowaniu ustroju rolnego obowiązujące od dnia 30 kwietnia 2016 r., „Krakowski Przegląd Notarialny” 2016, rok I, nr 2, s. 49-105; J. Grykiel, Ograniczenia obrotu nieruchomościami rolnymi oraz prawami udziałowymi w spółkach po nowelizacji ustawy o kształtowaniu ustroju rolnego, „Monitor Prawniczy” 2016, nr 12, s. 627-643; J. Pisuliński, O niektórych osobliwościach obrotu nieruchomościami rolnymi, „Rejent” 2016, nr 5, s. 23-48; A. Bieranowski, Dekompozycja konstrukcji zasiedzenia w nowym reżimie ograniczeń nabycia własności nieruchomości rolnej-zagadnienia węzłowe i uwagi de lege ferenda, „Rejent” 2016, nr 5, s. 80-92; K. Czerwińska-Koral, Pojęcie nieruchomości rolnej jako wyznacznik zasad obrotu nieruchomościami rolnymi, „Rejent” 2016, nr 6, s. 52-72.

5 Szerzej J. Bieluk, Nowe zasady dziedziczenia gospodarstw rolnych po nowelizacji ustawy o kształtowaniu ustroju rolnego, „Studia luridica Agraria” 2016, T. XIV, s. 75-88.

6 Ustawa z dnia 23 kwietnia 1964 r. Kodeks cywilny (Tekst jedn. Dz.U. z 2017 r. poz. 459 z późn. zm.), dalej: kc.
} 
ułamkowych. Nie ulega więc wątpliwości, iż do działu spadku stosuje się przepisy dotyczące znoszenia współwłasności, więc i odpowiednio przepisy u.k.u.r.

W myśl art. 210 § 2 kc., zniesienie współwłasności nieruchomości rolnej oraz gospodarstwa rolnego w rozumieniu u.k.u.r. następuje z uwzględnieniem przepisów tej ustawy. Konsekwencją przyjętego rozwiązania jest to, że w przypadku znoszenia współwłasności nieruchomości rolnej i działu spadku (do którego mają zastosowanie art. $210 \mathrm{i} \mathrm{n.} \mathrm{kc.)} \mathrm{konieczne} \mathrm{jest} \mathrm{zachowanie} \mathrm{określonej} \mathrm{procedury} \mathrm{zgodnej} \mathrm{z} \mathrm{wy-}$ mogami u.k.u.r.

\section{Pojęcie nieruchomości rolnej}

Zasadnicze znaczenie dla określenia zakresu oddziaływania u.k.u.r. ma pojęcie nieruchomości rolnej. Zgodnie z definicją zawartą w art. 2 pkt 4 u.k.u.r., przez nieruchomość rolną na potrzeby tej ustawy rozumie się nieruchomość rolną w rozumieniu kc., z wyłączeniem nieruchomości położonych na obszarach przeznaczonych w planach zagospodarowania przestrzennego na cele inne niż rolne. Nieruchomością rolną w rozumieniu u.k.u.r. jest więc nieruchomość, która: 1) jest nieruchomością rolną w rozumieniu art. $46^{1} \mathrm{kc}$. i jest jednocześnie przeznaczona w miejscowym planie zagospodarowania przestrzennego na cele związane bezpośrednio z produkcją rolną; 2) jest nieruchomością rolną w rozumieniu art. $46^{1} \mathrm{kc}$. i jest jednocześnie położona na terenie, dla którego brak jest miejscowego planu zagospodarowania przestrzennego. Pojęcie nieruchomości rolnej jest kluczowe dla ustalenia zakresu przedmiotowego u.k.u.r., gdyż ustawę stosuje się właśnie do nieruchomości rolnych ${ }^{7}$.

Zgodnie z art. 1a u.k.u.r. przepisów ustawy nie stosuje się do nieruchomości rolnych wchodzących w skład Zasobu Własności Rolnej Skarbu Państwa, o którym mowa w ustawie z dnia 19 października 1991 r. o gospodarowaniu nieruchomościami rolnymi Skarbu Państwa ${ }^{8}$, o powierzchni mniejszej niż 0,3 ha oraz będących drogami wewnętrznymi. Art. 11 ustawy z dnia 14 kwietnia 2016 r. o wstrzymaniu sprzedaży nieruchomości Zasobu Własności Rolnej Skarbu Państwa oraz o zmianie niektórych ustaw wyłącza spod działania ustawy jeszcze dwie kategorie gruntów, a mianowicie:

- grunty rolne zabudowane o powierzchni nieprzekraczającej 0,5 ha, które w dniu wejścia w życie ustawy zajęte są pod budynki mieszkalne oraz budynki, budowle i urządzenia niewykorzystywane obecnie do produkcji rolniczej, wraz z gruntami do nich przyległymi umożliwiającymi ich właściwe wykorzystanie oraz zajętymi na urządzenie ogródka przydomowego - je- 
Dział spadku obejmującego gospodarstwo rolne w świetle przepisów ustawy...

żeli grunty te tworzą zorganizowaną całość gospodarczą oraz nie zostały wyłączone z produkcji rolnej w rozumieniu ustawy z dnia 3 lutego $1995 \mathrm{r}$. o ochronie gruntów rolnych i leśnych ${ }^{9}$;

- nieruchomości rolne, które w dniu wejścia w życie ustawy w ostatecznych decyzjach o warunkach zabudowy i zagospodarowania terenu przeznaczone są na cele inne niż rolne.

Wyłączenia stosowania u.k.u.r. są więc bardzo nieznaczne. Jeżeli więc nieruchomość ma oznaczenie $\mathrm{R}$ w ewidencji gruntów i budynków oraz co najmniej $3000 \mathrm{~m}^{2}$, a nie zachodzą powyżej opisane wyjątki, to podlega przepisom u.k.u.r.

\section{Pojęcie nabycia nieruchomości rolnej}

Nowelizacja u.k.u.r. znacznie rozszerzyła pojęcie nabycia nieruchomości rolnej. Zgodnie z art. 2 pkt 7 u.k.u.r. przez nabycie nieruchomości rolnej należy rozumieć ,przeniesienie własności nieruchomości rolnej lub nabycie własności nieruchomości rolnej w wyniku dokonania czynności prawnej lub orzeczenia sądu albo organu administracji publicznej, a także innego zdarzenia prawnego". Nie ma więc wątpliwości, iż zniesienie współwłasności, jak też umowny i sądowy dział spadku w sytuacji, gdy w skład spadku wchodzi nieruchomość rolna, podlega przepisom u.k.u.r., w tym ograniczeniom wprowadzonym od 30 kwietnia 2016 r. Zastosowanie zatem mają ograniczenia podmiotowe związane z przymiotem rolnika indywidualnego oraz w określonych w ustawie sytuacjach KOWR przysługuje prawo wykupu w stosunku do gruntów rolnych będących przedmiotem współwłasności.

\section{Ograniczenia w nabywaniu nieruchomości rolnych}

Zgodnie z art. 2a ust. 1 u.k.u.r. nabywcą nieruchomości rolnej może być wyłącznie rolnik indywidualny, chyba że ustawa stanowi inaczej. Zgodnie z art. 6 ust. 1 u.k.u.r.: „Za rolnika indywidualnego uważa się osobę fizyczną będącą właścicielem, użytkownikiem wieczystym, samoistnym posiadaczem lub dzierżawcą nieruchomości rolnych, których łączna powierzchnia użytków rolnych nie przekracza $\mathbf{3 0 0}$ ha, posiadającą kwalifikacje rolnicze oraz co najmniej od $\mathbf{5}$ lat zamieszkała w gminie, na obszarze której jest położona jedna z nieruchomości rolnych wchodzących w skład gospodarstwa rolnego i prowadzącą przez ten okres osobiście to gospodarstwo".

Wyjątki od tej zasady określone są w ust. 3 art. 2a u.k.u.r. i dotyczą nabycia przez: osobę bliską zbywcy, jednostkę samorządu terytorialnego, Skarb Państwa lub działającą na jego rzecz agencję, osoby prawne działające na podstawie prze- 
pisów o stosunku Państwa do Kościoła katolickiego w Rzeczypospolitej Polskiej, o stosunku Państwa do innych kościołów i związków wyznaniowych oraz o gwarancjach wolności sumienia i wyznania, a także parki narodowe, w przypadku zakupu ${ }^{10}$ nieruchomości rolnych na cele związane $\mathrm{z}$ ochroną przyrody. Ustawa przewiduje również wyjątki ze względu na sposób nabycia, tj. w sytuacjach, w których nabycie nieruchomości rolnej następuje w wyniku dziedziczenia oraz zapisu windykacyjnego, na podstawie art. 151 lub art. $231 \mathrm{kc}$. oraz w toku postępowania restrukturyzacyjnego w ramach postępowania sanacyjnego. Nabycie nieruchomości rolnej możliwe jest też w innych przypadkach i przez inne podmioty niż wymienione powyżej, jednak wymagana jest do tego zgoda Prezesa Krajowego Ośrodka Wsparcia Rolnictwa ${ }^{11}$ na podstawie art. $2 \mathrm{a}$ ust. 4 u.k.u.r.

\section{Osoba bliska - pojęcie i stosunek do kręgu dziedziczenia}

Osoby bliskie wyłączone są z ograniczeń przy nabywaniu nieruchomości rolnych. Zgodnie z art. 2 pkt 6 u.k.u.r. przez osobę bliską należy rozumieć zstępnych, wstępnych, rodzeństwo, dzieci rodzeństwa, małżonka, osoby przysposabiające i przysposobione. Zauważyć należy, iż zakres ten nie pokrywa się z kręgiem osób dziedziczących ustawowo. Różnice są niewielkie, ale pojęcie osoby bliskiej nie obejmuje wnuków i dalszych zstępnych rodzeństwa, zstępnych dziadków oraz pasierbów. Trudno znaleźć uzasadnienie dla takiego wyłączenia. Pojęcie osoby bliskiej winno być $\mathrm{w}$ takiej sytuacji co najmniej tożsame $\mathrm{z}$ kręgiem osób dziedziczących ustawowo. Pominięto też osoby, które nie pozostają w związkach rodzinnych, ale są osobami bliskimi, na przykład ze względów uczuciowych. Wyeliminowano z tego kręgu osoby pozostające np. w związkach partnerskich. Jak zauważa H. Ciepła ${ }^{12}, \ldots$.tym katalogiem nie objęto osób pozostających faktycznie we wspólnym pożyciu. Unormowanie to oznacza wykluczenie tych osób z korzystania z ulgowych warunków nabywania nieruchomości rolnych. Moim zdaniem może ono nasuwać wątpliwości co do zgodności z konstytucyjną zasadą ochrony rodziny, zwłaszcza odnośnie do związków konkubenckich posiadających dzieci. W orzecznictwie jest bowiem ugruntowany pogląd, że konkubenci są osobami bliskimi. Brak jest też racji jurydycznych przemawiających za wyłączeniem pasierbów z katalogu osób bliskich”.

\section{Wyłączenie ze względu na sposób nabycia}

Zgodnie z art. 2a ust. 3 pkt 2 u.k.u.r. ograniczenia w nabywaniu nieruchomości rolnych nie dotyczą nabycia nieruchomości rolnej w wyniku dziedziczenia oraz zapisu windykacyjnego. Jednak ograniczenie to nie dotyczy działu spadku, a wy-

\footnotetext{
10 Zob. interesujące uwagi na temat pojęcia zakupu użytego w tym miejscu przez ustawodawcę, K. Maj, O potrzebie zmian w ustawie o kształtowaniu ustroju rolnego, „Krakowski Przegląd Notarialny” 2017, rok 2, nr 2, s. 31. Dalej: KOWR.

12 Zob. H. Ciepła, Aspekty prawne..., op. cit., s. 47
} 
łącznie samego dziedziczenia, tj. nabycia statusu spadkobiercy i przyjęcia spadku. Można przewidywać, że ograniczenia te mogą zniechęcać spadkobierców do przeprowadzania działu spadku, przez co przedłużać się będzie stan pozostawania przez nich we wspólności majątku spadkowego. Pojawiają się głosy, iż racjonalne byłoby rozciągnięcie zwolnienia z rygorów u.k.u.r. nabycia „,W wyniku dziedziczenia ustawowego" na dział spadku, jednak jest to interpretacja z pewnością słuszna co do zasadności rozwiązań ustawowych, ale wyraźnie odróżnić należy nabycie w drodze dziedziczenia od postępowania działowego, które to rozróżnienie uniemożliwia tak daleko idącą interpretację ${ }^{13}$.

\section{Wyłączenia z obowiązków związanych z nabyciem nieruchomości rolnej}

Kolejnym ograniczeniem wynikającym z nowej regulacji jest obowiązek prowadzenia gospodarstwa rolnego, w skład którego weszła nabyta nieruchomość rolna, przez okres co najmniej 10 lat od dnia nabycia tej nieruchomości, a w przypadku osoby fizycznej prowadzenia tego gospodarstwa osobiście. W tym okresie nabyta nieruchomość nie może być zbyta ani oddana w posiadanie innym podmiotom (art. 2b ust. 1 i 2 u.k.u.r.). Obowiązku tego nie stosuje się do podmiotów, o których mowa w art. 2a ust. 3 pkt 1 u.k.u.r. (osoba bliska zbywcy) oraz do nabywców nieruchomości rolnej w przypadkach, o których mowa w art. 2a ust. 3 pkt 2 u.k.u.r., tj. w wyniku dziedziczenia oraz zapisu windykacyjnego i pkt 3 (na podstawie art. 151 lub art. 231 kc.). W takiej sytuacji mamy do czynienia z zakresem ograniczeń podobnym jak przy nabywaniu nieruchomości rolnej. Osoba bliska w rozumieniu ustawy oraz osoba nabywająca nieruchomość rolną w drodze dziedziczenia oraz zapisu windykacyjnego nie jest później ograniczona w możliwości dysponowania nabytą nieruchomością, ani nie jest zobowiązana do prowadzenia gospodarstwa rolnego. Stanowisko to potwierdził Sąd Najwyższy w uchwale z dnia 22 czerwca 2017 r. ${ }^{14}$ : „Zbycie nieruchomości rolnej przez nabywcę przed upływem okresu przewidzianego w art. 2b ust. 1 ustawy z dnia 11 kwietnia 2003 r. o kształtowaniu ustroju rolnego (jedn. tekst: Dz.U. z 2016 r. poz. 2052) osobie bliskiej w rozumieniu art. 2 pkt 6 wymienionej ustawy nie wymaga zgody sądu wydanej na podstawie art. 2b ust. 3 tej ustawy". Jednak podmiot, który nie jest osobą bliską, a w wyniku działu spadku otrzyma nieruchomość rolną, będzie obarczony powyższym obowiązkiem.

Zob. wypowiedź J. Góreckiego w dyskusji Sprawozdanie z IX Kolokwium Jagiellońskiego. Ograniczenia w obrocie nieruchomościami rolnymi, „Krakowski Przegląd Notarialny” 2017, rok 2, nr 2, s. 163: „Ja chciałbym tylko odnieść się do tej jednej kwestii dotyczącej działu spadku. Uważam, że kluczem, który może umożliwić objęcie działu spadku także za pomocą tych zwolnień, o których tutaj mowa, jest użycie, być może przypadkowe, słów «w wyniku dziedziczenia ustawowego», dlatego że jest to takie sformułowanie, które nie wskazuje wcale, że chodzi tylko i wyłącznie o samo nabycie w drodze dziedziczenia ustawowego, ale także w oparciu o to, co dzieje się w jego wyniku, a w wyniku dziedziczenia ustawowego przez kilku spadkobierców powinien nastąpić dział spadku i dlatego w moim przekonaniu można to tak interpretować". 


\section{Ograniczenia działu spadku obejmującego nieruchomości rolne}

W sytuacji gdy współspadkobiercy dzielący spadek nie są osobami bliskimi mogą powstać sytuacje, w których dział spadku będzie utrudniony, gdyż żaden ze spadkobierców nie spełnia warunków niezbędnych do uzyskania statusu rolnika indywidualnego. Może to nastąpić np. w sytuacji, gdy grunty, na których gospodarowali, leżą w innej gminie niż miejsce ich zamieszkania lub gdy np. wydzierżawili gospodarstwo rolne - więc nie spełniają przesłanek samodzielnego podejmowania decyzji itd. W przypadku gdy współspadkobierca, który chce przejąć własność gospodarstwa rolnego albo nieruchomości rolnej (art. 212 § 2 kc.) lub jej części (w przypadku podziału fizycznego - art. $211 \mathrm{kc}$.) nie będzie rolnikiem indywidualnym, potrzebna będzie zgoda Prezesa KOWR. Przesłanki do uzyskania takiego pozwolenia określone są $\mathrm{w}$ art. $2 \mathrm{a}$ u.k.u.r. ${ }^{15} \mathrm{~W}$ przypadku braku zgody, wnioskodawca może żądać od KOWR złożenia oświadczenia o nabyciu tej nieruchomości za zapłatą równowartości pieniężnej odpowiadającej jej wartości rynkowej (art. 2a ust. 6 u.k.u.r.).

Jeżeli jednak współspadkobiercy, którzy nie uzyskali zgody KOWR na przyznanie nieruchomości rolnej jednemu z nich, nie złożą takiego żądania, wówczas niemożliwe będzie przeprowadzenie działu spadku, w którego skład wchodzi grunt rolny poprzez jego podział fizyczny, nawet jeżeli nieruchomość rolna będąca przedmiotem współwłasności nadaje się do podziału (np. nieruchomość o powierzchni 100 ha). W takim wypadku można przeprowadzić dział spadku poprzez podział cywilny, tj. sprzedaż nieruchomości na rzecz innego podmiotu (zob. art. 214 kc.) najlepiej na rzecz rolnika indywidualnego, aby nie było konieczne uzyskanie zgody przez KOWR, oraz następnie podział uzyskanej ceny pomiędzy spadkobierców. Nie jest to jednak rozwiązanie idealne, współspadkobiercy mogą być zainteresowani bardziej uzyskaniem własności nieruchomości, a nie jej równowartości pieniężnej. Mogą być także sytuacje, w których nawet podział cywilny jest niemożliwy, gdyż nie ma zainteresowanych do zakupu nieruchomości rolnej należącej do spadku (zwłaszcza wobec znacznych ograniczeń w nabywaniu nieruchomości rolnych wprowadzonych przez u.k.u.r. w aktualnym brzmieniu). Jeżeli zatem opisane powyżej rozwiązania zawiodą, nieruchomość rolna pozostanie w dalszym ciągu przedmiotem należącym do wspólnej masy spadkowej, tym samym przyznane na mocy art. $210 \S 1 \mathrm{kc}$. prawo żądania zniesienia współwłasności zostanie w praktyce ograniczone, pomimo że uprawnienie to może być wyłączone jedynie przez czynność prawną i to na czas nie dłuższy niż lat pięć (art. $210 \S 1 \mathrm{zd} .2 \mathrm{kc}$. ${ }^{16}$. W praktyce dział spadku (podobnie zniesienie współwłasności) w inny sposób niż skierowanie żądania wykupu nieruchomości do KOWR może okazać się niemożliwe. Tego rodzaju 
Dział spadku obejmującego gospodarstwo rolne w świetle przepisów ustawy...

znaczne ograniczenie swobody dysponowania własnością budzi poważne wątpliwości konstytucyjne.

\section{Sposoby działu spadku}

Zgodnie z kodeksem cywilnym rzecz wspólna może być albo podzielona fizycznie, albo przyznana jednemu ze spadkobierców z obowiązkiem spłaty pozostałych, albo może być dokonany podział cywilny - sprzedaż rzeczy i podział uzyskanych środków ${ }^{17}$. W sytuacji podziału cywilnego sprzedaż musi nastąpić z uwzględnieniem przepisów u.k.u.r. W przypadku przyznania jednemu ze spadkobierców również winien spełniać on warunki określone w u.k.u.r., aby móc nieruchomość otrzymać. W przypadku podziału fizycznego nieruchomości wspólnej między spadkobierców, w sytuacji, gdy otrzymane części odpowiadają wielkości udziałów, w literaturze pojawiają się zdania, iż wówczas u.k.u.r. nie powinien być stosowany ${ }^{18}$. Jednak nawet uznając zasadność rozumowania, iż nie dochodzi wówczas do nabycia nieruchomości w rozumieniu art. 2 a pkt 7 u.k.u.r. ${ }^{19}$, zauważyć należy, że po pierwsze uzyskanie równych części w praktyce działowej jest bardzo trudne, o ile w ogóle możliwe (pojawia się np. pytanie, czy równe części odnoszą się do powierzchni czy do wartości nieruchomości). Po drugie, sankcja nieważności jest bardzo poważnym skutkiem uznania, iż ryzyko związane z nieważnością tego rodzaju postępowania działowego (art. 9 u.k.u.r.). Po trzecie, umieszczenie w art. 210 kc. wyraźnego zapisu, iż znoszenie współwłasności nieruchomości rolnej następuje z uwzględnieniem przepisów tej ustawy, wskazuje wyraźnie na intencję ustawodawcy objęcia wszelkich postępować działowych rygorami u.k.u.r. Z pewnością powyższe problemy interpretacyjne wymagają ingerencji ustawodawcy, a co najmniej winny być rozstrzygnięte przez orzecznictwo. Zauważyć należy, iż w przypadku sądowego działu spadku, postanowienie podlega tylko kontroli instancyjnej (o czym poniżej).

\section{Sądowy dział spadku}

Do sądowego działu spadku stosujemy przepisy kodeksu cywilnego dotyczące zniesienia współwłasności. Sąd stosując art. 213 i następne kc. ma za zadanie badać zgodność podziału z zasadami prawidłowej gospodarki rolnej oraz to, czy ewentualny podziału gospodarstwa lub przyznanie go jednemu z uczestników postępowania są zgodne z przepisami u.k.u.r. Tak więc sąd winien badać, czy spadkobierca ma-

Oczywiście możliwe są różne warianty wspomnianych sposobów, jednak dla jasności wywodu dokonano uproszczeń w tym zakresie.

18 Zob. interesujące rozważania B. Swaczyny, Zniesienie współłłasności nieruchomości rolnej po 29.04.2016 r., „Rejent” 2017, nr 7, s. 91 i wnioski z tych rozważań: jeżeli żaden ze współwłaścicieli nie ma kwalifikacji rolniczych, co do zasady wyjście z niepodzielności może nastąpić przez podział nieruchomości rolnej na części odpowiadające udziałom współwłaścicieli (tutaj ustawa o kształtowaniu ustroju rolnego w ogóle nie ma zastosowania) bądź jej sprzedaż osobie o takich kwalifikacjach.

Tamże, s. 86-87. 
jący otrzymać gospodarstwo rolne (lub część tego gospodarstwa w przypadku podziału fizycznego) spełnia przesłanki z art. 2a u.k.u.r. Jeżeli przesłanki te nie są spełnione, sąd może zawiesić postępowanie działowe na czas potrzebny dla uzyskania zgody Prezesa KOWR ${ }^{20}$.

Sąd ma obowiązek zbadać, czy nabycie nieruchomości rolnej jest zgodne z u.k.u.r. Jednak w przypadku, gdy postanowienie sądu dotyczące działu spadku zapadnie z naruszeniem przepisów u.k.u.r., KOWR nie ma możliwości i kompetencji, aby takie postanowienie weryfikować ${ }^{21}$. Podlega ono wyłącznie trybowi kontroli sądowej (apelacja, ewentualnie kasacja).

\section{Zgoda Prezesa KOWR}

Okolicznością wyłączającą zastosowanie zasady przewidzianej w art. 2a ust. 1 u.k.u.r. jest zgoda Prezesa KOWR. Zgodnie z art. 2a ust. 4 u.k.u.r., „Nabycie nieruchomości rolnej przez inne podmioty niż wymienione w ust. $1 \mathrm{i}$ ust. 3 pkt 1 oraz w innych przypadkach niż wymienione w ust. 3 pkt 2-4, może nastąpić za zgodą Prezesa KOWR, wyrażoną w drodze decyzji administracyjnej, wydanej na wniosek:

1) zbywcy, jeżeli:

a) wykaże on, że nie było możliwości nabycia nieruchomości rolnej przez podmioty, o których mowa w art. 2a ust. 1 i 3 ,

b) nabywca daje rękojmię należytego prowadzenia działalności rolniczej,

c) w wyniku nabycia nie dojdzie do nadmiernej koncentracji gruntów rolnych;

2) osoby fizycznej zamierzającej utworzyć gospodarstwo rodzinne, która:

a) posiada kwalifikacje rolnicze albo której, pod warunkiem uzupełnienia kwalifikacji zawodowych, przyznano pomoc [z funduszy europejskich] (...), a termin na uzupełnienie tych kwalifikacji jeszcze nie upłynął,

b) daje rękojmię należytego prowadzenia działalności rolniczej,

c) zobowiąże się do zamieszkiwania w okresie 5 lat od dnia nabycia nieruchomości na terenie gminy, na obszarze której położona jest jedna z nieru-

Zob. P. Księżak, (w:) Kodeks cywilny. Komentarz, K. Osajda (red.), Komentarz do art. 213 kc., Legalis.

Tak zasadnie P. Księżak, tamże, „Jeżeli sąd przyzna gospodarstwo rolne współwłaścicielowi, o którym mowa w art. 213 kc., z naruszeniem przepisów UstRolU, dochodzi do naruszenia przepisów prawa materialnego, które może być podstawą apelacji. Jednakże prawomocne postanowienie o zniesieniu współwłasności stanowi podstawę nabycia, mimo tego materialnoprawnego uchybienia". Zob. też interesujące rozważania A.J. Szeredy na temat skuteczności postanowień sądu w kontekście uprawnień ANR (obecnie KOWR), Problematyka orzeCzenia sądu w ustawie o kształtowaniu ustroju rolnego, „Krakowski Przegląd Notarialny” 2016, rok 1, nr 4, s. 107 in. 
chomości rolnych, która wejdzie w skład tworzonego gospodarstwa rodzinnego.

Przesłanki te budzą szereg wątpliwości co do ich zasadności i precyzji sformułowania ${ }^{22}$. Działania KOWR (wcześniej ANR), obserwowane przez autora, wskazują, iż praktyka w zakresie udzielania zgód jest dosyć liberalna i do rzadkości należą sytuacje, w których następuje odmowa udzielenia zgody na nabycie ${ }^{23}$.

\section{Prawo nabycia}

W przypadku działu spadku KOWR przysługuje prawo nabycia. Jest ono wyłączone wtedy, gdy nabywcą jest osoba bliska lub rolnik indywidualny. To, że dana kategoria osób może nabyć nieruchomość rolną nie wyklucza prawa nabycia przysługującego KOWR. Zgodnie z treścią przepisu art. 4 ust. 1 u.k.u.r., jeżeli nabycie nieruchomości rolnej następuje w wyniku:

1) zawarcia umowy innej niż umowa sprzedaży lub

2) jednostronnej czynności prawnej, lub

3) orzeczenia sądu, organu administracji publicznej albo orzeczenia sądu lub organu egzekucyjnego wydanego na podstawie przepisów o postępowaniu egzekucyjnym, lub

4) innej czynności prawnej lub innego zdarzenia prawnego, w szczególności:

a) zasiedzenia nieruchomości rolnej, dziedziczenia oraz zapisu windykacyjnego, którego przedmiotem jest nieruchomość rolna lub gospodarstwo rolne,

b) podziału, przekształcenia bądź łączenia spółek handlowych

KOWR działająca na rzecz Skarbu Państwa może złożyć oświadczenie o nabyciu tej nieruchomości za zapłatą równowartości pieniężnej odpowiadającej jej wartości rynkowej.

Z prawem nabycia związany jest także obowiązek zawiadomienia KOWR o fakcie nabycia nieruchomości rolnej (art. 4 ust. 5 u.k.u.r.). Zawiadomienia o nabyciu własności nieruchomości rolnej w przypadku działu spadku, którego przedmiotem jest nieruchomość rolna lub gospodarstwo rolne, dokonuje ten ze spadkobierców, który nabędzie ich własność. W przypadku sądowego działu spadku, zgodnie z art. 4 ust. 5 lit b) u.k.u.r., zawiadomienia dokonać winien sąd. na-bija-w-zasady-wolego-rynku.html - „Od 30 kwietnia 2016 r. do 31 marca 2017 r. do ANR wpłynęło 11106 wniosków o przeniesienie własności nieruchomości rolnych. ANR rozpatrzyła z tego już 6751 wniosków. W 6658 przypadków zgodziła się na sprzedaż ziemi o łącznej powierzchni 19735 ha (92 proc. wszystkich decyzji). Tylko w 93 wypadkach powiedziała «nie» (1 proc. decyzji)". 
Prawo nabycia będzie miało stosunkowo niewielkie zastosowanie, gdyż wyłączone jest w dwóch najczęściej spotykanych sytuacjach, gdy nabywcami są osoby bliskie oraz rolnicy indywidualni. Jednak w szeregu sytuacjach powstanie obowiązek zawiadomienia KOWR o dziale spadku ${ }^{24}$. Prawo nabycia KOWR nie przysługuje zgodnie $\mathrm{z}$ art. 4 ust. 4 u.k.u.r.:

1) jeżeli w wyniku przeniesienia własności nieruchomości rolnej następuje powiększenie gospodarstwa rodzinnego, jednak do powierzchni nie większej niż określona w art. 5 ust. 1 pkt 2 u.k.u.r.;

2) jeżeli nabycie nieruchomości rolnej następuje:

a) za zgodą, o której mowa w art. 2a ust. 4 u.k.u.r., albo za zgodą, o której mowa w art. 29a ust. 3 pkt 1 lit. b ustawy z dnia 19 października 1991 r. o gospodarowaniu nieruchomościami rolnymi Skarbu Państwa, lub

b) przez osobę bliską zbywcy,

c) w wyniku dziedziczenia ustawowego albo dziedziczenia przez rolnika indywidualnego,

d) przez rolnika indywidualnego w wyniku zapisu windykacyjnego;

3) jeżeli przeniesienie własności nieruchomości rolnej następuje w wyniku umowy z następcą, o której mowa w art. 84 ustawy z dnia 20 grudnia 1990 r. o ubezpieczeniu społecznym rolników ${ }^{25}$;

4) jeżeli przeniesienie własności nieruchomości rolnej następuje między osobami prawnymi, o których mowa w art. 2a ust. 3 pkt 1 lit. d) u.k.u.r., tego samego kościoła lub związku wyznaniowego.

\section{Udziały lub akcje spółek będących właścicielami nieruchomości rolnych}

Zgodnie z art. 3a u.k.u.r. ograniczeniu podlega również obrót akcjami i udziałami spółek będących właścicielami nieruchomości rolnych. Przepis art. 3b u.k.u.r. rozciąga te ograniczenia na całość praw i obowiązków wspólnika spółki osobowej. W przypadku działu spadku obejmującego udziały (akcje) spółki kapitałowej, KOWR przysługuje prawo nabycia udziałów (akcji) zgodnie z art. 4 ust. 6 u.k.u.r., ograniczone jednak zgodnie z art. 4 ust. 4 powyższej ustawy.

W takich sytuacjach, gdy przedmiotem działu spadku są prawa wspólnika spółki osobowej, która jest właścicielem nieruchomości rolnej, KOWR działający na rzecz Skarbu Państwa może złożyć oświadczenie o nabyciu tej nieruchomości za zapłatą równowartości pieniężnej odpowiadającej jej wartości rynkowej. Równowartość 
pieniężną KOWR określa przy zastosowaniu sposobów ustalania wartości nieruchomości przewidzianych w przepisach o gospodarce nieruchomościami.

Wyłączenia są w takim przypadku dużo węższe, a mianowicie zgodnie z art. 3a ust. 6 u.k.u.r. KOWR nie ma prawa nabycia nieruchomości wtedy, gdy:

1) zamiast dotychczasowego wspólnika wspólnikiem staje się osoba jemu bliska;

2) nowym wspólnikiem staje się osoba bliska któregokolwiek ze wspólników.

\section{Zagadnienia końcowe}

Dział spadku obejmującego gospodarstwo rolne został od 30 kwietnia 2016 r. objęty rygorami u.k.u.r. Ustawa ta przewiduje szereg ograniczeń w nabywaniu nieruchomości rolnych. Zasadą jest nabycie gruntów rolnych przez rolnika indywidualnego. Osoby bliskie są wyłączone z rygorów u.k.u.r. Ponieważ zdecydowana większość postępowań działowych ma miejsce między osobami bliskimi (z reguły spadkobiercami ustawowymi), to ograniczenia zawarte w omawianych regulacjach mają mniejsze znaczenie. Jednak w sytuacji, gdy dział spadku odbywa się między osobami niemieszczącymi się w definicji osób bliskich, do takiego działu mają zastosowanie ograniczenia zawarte w u.k.u.r. Stosowanie powyższych rygorów do działu spadku nie jest zrozumiałe i nie służy żadnym celom określonym w preambule tejże ustawy ${ }^{26}$. Niepotrzebnie komplikuje to obrót. Na szczęście wyłączone są z tych ograniczeń najczęściej spotykane działy spadku, w których uczestniczą osoby sobie bliskie. W pozostałych przypadkach, postępowanie pomiędzy spadkobiercami może powodować znaczne trudności. skiej stanowią podstawę ustroju rolnego Rzeczypospolitej Polskiej, dla zapewnienia właściwego zagospodarowania ziemi rolnej w Rzeczypospolitej Polskiej, w trosce o zapewnienie bezpieczeństwa żywnościowego obywateli i dla wspierania zrównoważonego rolnictwa prowadzonego w zgodzie z wymogami ochrony środowiska i sprzyjającego rozwojowi obszarów wiejskich, uchwala się niniejszą ustawę". 


\section{DIVISION OF INHERITANCE COMPRISING A FARM IN THE LIGHT OF THE PROVISIONS OF THE ACT ON THE FORMATION OF AGRICULTURAL SYSTEM}

Keywords: shaping of agricultural system, agricultural real estate, The National Center for Support of Agriculture, agricultural land turnover, division of inheritance

The Polish legislator introduced a series of mechanisms limiting the possibility of turnover of agricultural real estate. The amendment to the Act on the Formation of Agricultural System, binding since 30 April 2016, has introduced several limitations in the acquisition of agricultural real estate. The rule has been adopted that only an individual farmer may be the acquirer of farming land, which excludes e.g. a commercial law company.

These limitations also apply to the division of inheritance. The acquisition by relatives is not subject to the restrictions contained in the discussed regulation, but the inheritance by non-relatives is only possible under the statutory requirements. In the division of inheritance, the estate may be acquired by an individual farmer, or by other subjects who obtained the approval of the President of the National Center for Support of Agriculture. The inclusion of the above clauses in the inheritance section is not understandable and does not serve any purposes defined in the preamble to the law. It unnecessarily complicates the turnover. Fortunately, the most common divisions of inheritance, i.e. those in which relatives participate, are excluded from these constraints.

\section{Bibliografia:}

Bieluk J., Nowe zasady dziedziczenia gospodarstw rolnych po nowelizacji ustawy o kształtowaniu ustroju rolnego, „Studia Iuridica Agraria” 2016, T. XIV.

Bieluk J., Ustawa o kształtowaniu ustroju rolnego. Komentarz, Warszawa 2016.

Bieranowski A., Dekompozycja konstrukcji zasiedzenia w nowym reżimie ograniczeń nabycia własności nieruchomości rolnej - zagadnienia węzłowe i uwagi de lege ferenda, ,Rejent” 2016, nr 5.

Ciepła H., Aspekty prawne obrotu gruntami rolnymi od 30.04.2016 r. o kształtowaniu ustroju rolnego oraz w ustawie z dnia 14.04.2016 r. o wstrzymaniu sprzedaży nieruchomości Zasobu Własności Rolnej Skarbu Państwa, „Rejent” 2016, nr 9.

Czerwińska-Koral K., Pojęcie nieruchomości rolnej jako wyznacznik zasad obrotu nieruchomościami rolnymi, „Rejent” 2016, nr 6.

Grykiel J., Ograniczenia obrotu nieruchomościami rolnymi oraz prawami udziałowymi w spółkach po nowelizacji ustawy o kształtowaniu ustroju rolnego, „Monitor Prawniczy” 2016, nr 12.

Krupa-Dąbrowska R., Państwo wtrąca się do rozwodów rolników, „Rzeczpospolita” z 9 maja 2016 r. 
Krupa-Dąbrowska R., Przepisy ograniczające handel ziemią rolną biją w zasady wolnego rynku, „Rzeczpospolita” z 25 kwietnia 2017 r., http://www.rp.pl/Rolnicy/304259883-Przepisy-ograniczajace-handel-ziemia-rolna-bija-w-zasady-wolego-rynku.html

Maj K., O potrzebie zmian w ustawie o kształtowaniu ustroju rolnego, „Krakowski Przegląd Notarialny" 2017, rok 2, nr 2.

Maj K., Zmiany w ustawie o kształtowaniu ustroju rolnego obowiązujące od dnia 30 kwietnia 2016 r., „Krakowski Przegląd Notarialny” 2016, rok I, nr 2.

Pisuliński J., O niektórych osobliwościach obrotu nieruchomościami rolnymi, „Rejent” 2016, nr 5.

Sprawozdanie z IX Kolokwium Jagiellońskiego. Ograniczenia w obrocie nieruchomościami rolnymi „Krakowski Przegląd Notarialny” 2017, rok 2, nr 2.

Swaczyna B., Zniesienie współwłasności nieruchomości rolnej po 29.04.2016 r., „Rejent” 2017, nr 7.

Szereda A.J., Problematyka orzeczenia sądu w ustawie o kształtowaniu ustroju rolnego, „Krakowski Przegląd Notarialny" 2016, rok 1, nr 4.

Truszkiewicz Z., Nieruchomość rolna i gospodarstwo rolne w rozumieniu U.K.U.R., „Krakowski Przegląd Notarialny" 2016, nr 2. 